\title{
Growth rates of diatoms from coastal Antarctic waters estimated by in situ dialysis incubation
}

\author{
Maria Paola Mura*, Susana Agustí \\ Centro de Estudios Avanzados de Blanes, CSIC, Camí de Santa Bárbara s/n, E-17300 Blanes, Girona, Spain
}

\begin{abstract}
Growth rates of phytoplankton (cell diameter $<200 \mu \mathrm{m}$ ) were examined using dialysis bags incubated in situ at 3 coastal sites around the Antarctic Peninsula during the austral summer of 1994. The phytoplankton community, which was similar for all 3 sites, was dominated by diatoms of the genera Thalassiosira sp., Nitzschia sp., and Chaetoceros sp. The picophytoplankton community (cell diameter $<5 \mu \mathrm{m}$ ) did not increase inside the dialysis bags; however, the diatom populations grew at high growth rates (mean $\pm \mathrm{SE}=0.39 \pm 0.18 \mathrm{~d}^{-1}$ ). The growth rates of diatoms measured in the natural community were, however, close to 0 (mean $\pm \mathrm{SE}=-0.05 \pm 0.22 \mathrm{~d}^{-1}$ ), indicative of a close balance between growth and losses (population loss rate: mean $\pm \mathrm{SE}=0.45 \pm 0.43 \mathrm{~d}^{-1}$ ). The highest observed growth rates closely approached the maximal predicted growth rates from the cell size of the diatoms for the in situ temperature of $1.5^{\circ} \mathrm{C}$. These results indicate that coastal Antarctic phytoplankton can grow at or near, the maximal rates at the low in situ temperatures. The observation that loss rates are similar to population growth rates helps explain the low biomass of coastal Antarctic phytoplankton relative to the high nutrient availability in these waters.
\end{abstract}

KEY WORDS: Growth rates - Diatoms · Antarctıc Sea $\cdot$ Dialysis incubation

\section{INTRODUCTION}

Growth rates of Antarctic phytoplankton are reported to be low (Holm-Hansen et al. 1977, El-Sayed \& Taguchi 1981, Sommer 1989, Figueiras et al. 1994). Possible causes for these low growth rates are the low light levels (Hasle 1969, Holm-Hansen et al. 1977, Sakshaug \& Holm-Hansen 1984) and the low ambient temperature (Neory \& Holm-Hansen 1982, Jacques 1983, Tilzer \& Dubinsky 1987, Sommer 1989) characteristic of these waters. The general tendency for a decline in maximum algal growth rate with decreasing temperature (Eppley 1972, Goldman \& Carpenter 1974) supports the hypothesis that temperature could be responsible for the low growth rate of Antarctic phytoplankton. It may be, therefore, that the low growth rates of Antarctic phytoplankton are close to the maximal growth rates possible at the low temperatures of Antarctic waters.

\footnotetext{
•E-mail:paola@azathoth.ceab.es
}

The question of how close the growth rates realised in Antarctic waters are to maximal phytoplankton growth rates is as yet unresolved. One of the reasons for this is the diversity of techniques used to assess growth rates, most of which involve incubations of samples enclosed in bottles. The manipulation of Antarctic phytoplankton samples may disturb the community, leading to an underestimation of growth rates, since small changes in temperature during manipulation may induce substantial mortality (e.g. S. Agustí unpubl. results). Determination of the highest growth rates of Antarctic phytoplankton and how often they are realised requires, therefore, the application of techniques that minimize the sources of disturbance.

The incubation of natural phytoplankton communities enclosed within dialysis bags suspended in situ has been identified as one of the most reliable approaches to estimate the in situ growth rates of marine phytoplankton (Furnas 1990). The adequacy of dialysis bag experiments is based on the fact that they allow the maintenance of chemical contact between the population enclosed and the surrounding medium, and also 
that they are relatively unspecified, thereby allowing estimation of growth rates for a wide range of taxa (Furnas 1990). The major weaknesses of the estimation of algal growth rates using incubation in dialysis bags are the relatively long time required relative to other techniques (e.g. tracer incorporation) and the possibility that grazers are included in the bags even after screening. The problem of enclosing grazers within dialysis bags is somewhat less in Antarctic waters where the main grazers are often large (i.e. salps and krill).

We report here, based on incubations of natural communities enclosed within dialysis bags suspended in situ, the variability of gross and net growth rates of Antarctic phytoplankton communities during austral summer at 3 coastal locations off the Antarctic Peninsula. We examined population growth rates (inside the bags) and net population change (in the ambient water) for the main groups of the phytoplankton community, as weil as the total community in these waters. The results obtained allowed (1) the determination of the highest growth rates (achieved inside the dialysis bags) for Antarctic phytoplankton growing at low ambient temperature and irradiance, and (2) the comparison between the size-dependence of the highest growth rate observed and those predicted by general allometric models (Banse 1982, Sommer 1989).

\section{METHODS}

The experiments were conducted between February 4 and 24, 1994, during the BENTART-94 cruise around Antarctic waters, off Livingston Island (Sur and Falsa Bays) and Decepcion Island (Foster Port) on board the Spanish RV 'BIO Hespérides'. Three permanent stations between 100 and $200 \mathrm{~m}$ from the coastline were established and marked with moorings and buoys at each of the 3 coastal sites studied (depth 7 to $12 \mathrm{~m}$ ), all of which had very steep bathymetries. Three growth experiments were successfully conducted in Sur Bay $\left(62^{\circ} 39^{\prime} 80^{\prime \prime} \mathrm{S}, 60^{\circ} 24^{\prime} \mathrm{W}\right)$ and Falsa Bay $\left(62^{\circ} 43^{\prime} 90^{\prime \prime} \mathrm{S}\right.$, $\left.60^{\circ} 20^{\prime} 50^{\prime \prime} \mathrm{W}\right)$, and one in Foster Port $\left(62^{\circ} 49^{\prime} 15^{\prime \prime} \mathrm{S}\right.$, $\left.60^{\circ} 39^{\prime} 18.5^{\prime \prime} \mathrm{W}\right)$. All of the experiments initiated were successfully recovered, except for Fostcr Port, where only 1 of the 3 experiments deployed could be recovered, the other 2 being lost due to strong currents. The experiments involved the examination of apparent growth rates of phytoplankton enclosed within dialysis bags, and suspended in situ at about $1.5 \mathrm{~m}$ below the surface. Dialysis cultures consisted of surface $(5 \mathrm{~m})$ seawater, sampled at each station using Niskin bottles operated by a rosette sampling system and filtered through a $150 \mu \mathrm{m}$ mesh to exclude macrozooplankters. Four to six replicate dialysis bags, depending on the duration of the experiment, were prepared for each experiment. The bags, with a volume of $500 \mathrm{ml}$, were built with dialysis membranes with a molecular weight cut-off (MWCO) of 6000 to 8000 . This MWCO allowed diffusion of molecules smaller than proteins, which equilibrate rapidly with ambient sea water $(<4$ h, Mura et al. 1996). Dialysis bags were hydrated by soaking them in deionized water for $2 \mathrm{~h}$ prior to use. Once filled, they were carefully tied to a frame and suspended at $1.5 \mathrm{~m}$ depth in the water, until collected. The dialysis bags were incubated at shallower depths than that of sample collection $(1.5 \mathrm{~m}$ instead $5 \mathrm{~m})$ to compensate for shading by the frame and the membranes themselves, which reduced incident photosynthetically active radiation (PAR) by $26 \%$. Duplicated dialysis bags were retrieved $>2$ d later, this being the minimum time estimated in preliminary trials for a significant growth to occur. The duration of the experiments ranged from $3 \mathrm{~d}$, the time needed to observe a reliable growth response, to $15 \mathrm{~d}$, the time interval between visits to the farthest station. New experiments were deployed after each collection (Table 1). Changes in phytoplankton abundance in parallel samples of ambient subsurface waters collected during the experiments were used as controls and were assumed to represent the net rates of population change (Tóth 1980, Furnas 1982, 1990, Mura et al. 1996). The incubations were conducted within sheltered bays where currents are much reduced relative to open-sea currents as indicated by long-term ( $>5$ yr) current meter moorings. Hence the communities sampled at the beginning and end of each individual experiment ( 3 to 9 d) were not significantly influenced by replacement of water masses

We measured vertical profiles of temperature and salinity using a Mark V CTD, and fluorescence and spectral irradiance (whenever the stations were visited during the day) using a Li-Cor spectroradiometer. These profiles were obtained daily at Sur Bay and every 2 and 3 d at Falsa Bay and Foster Port, respectively, at a deeper $(100 \mathrm{~m})$ site adjacent to the moorings. Subsurface water samples were collected for dissolved inorganic nutrients, chlorophyll a (chl a) concentrations, and phytoplankton biovolume. A variable water volume 150 to $500 \mathrm{ml}$, depending on phytoplankton biomass) was filtered through Whatman GF/F filters for fluorometric analysis of chl a concentration (Parsons et al. 1984). The filtered material was homogenised, refrigerated at $15^{\circ} \mathrm{C}$ in $90 \%$ acetone, extracted for $6 \mathrm{~h}$ in the dark, and fluorescence measured using a Turner Designs fluorometer calibrated with pure chl a (Sigma Co.) (Holm-Hansen \& Riemann 1978). An additional sample (100 to $250 \mathrm{ml}$ ) was preserved with glutaraldehyde (final concentration of $1.5 \%)$ for microscopic examination of phytoplankton. These samples were filtered at low pressure onto black 
Nuclepore filters $(0.8 \mu \mathrm{m}$ nominal pore size), and then stained with $1 \mathrm{ml}$ of DAPI [4',6-diamdino-2-phenlindole), a DNA-specific stain, solution $\left.\left(10 \mu \mathrm{g} \mathrm{ml}^{-1}\right)\right]$ for 5 to 10 min without vacuum. (Martinussen \& Thingstad 1991). Filters were then washed twice with filtered sea water before they were mounted on a glass slide over a drop of Zeiss immersion oil, and stored frozen until microscopical examination at the laboratory.

Nitrate, phosphate, and silicate concentrations were estimated using an autoanalyzer following standard procedures (Whitledge et al. 1981). The CTD profiles were used to characterise the water masses and to calculate the thickness of the upper mixed layer (UPM) as an index of the stability of surface water column. The thickness of the UPM was taken as the shallowest depth at which water density $\left(\sigma_{i}\right)$ differs from surface values by more than $0.05 \mathrm{~kg} \mathrm{~m}^{-3}$ (Mitchell \& HolmHansen 1991, Mura et al. 1995). The UPM depth calculated in this way indicated the extent of the neutral stable layer that wind-driven turbulence should mix (Mann \& Lazier 1991).

Epifluorescence microscopy, which allows discrimination of autotrophic (i.e. containing chl a) and heterotrophic cells, was used to identify, enumerate, and measure phytoplankton cells. The phytoplankton cells collected on the filters were examined using a ZEISS AXIOPLAN microscope equipped with an epifluorescence unit provided with an UV filter set (Zeiss filter 487701 ). The filters were examined at 400 and $1000 \times$ magnifications to count cells larger ( 40 to 50 fields) and smaller (30 fields) than $5 \mu \mathrm{m}$, respectively (i.e. minimum 60 cells counted per taxon, average 200). Cells $>5 \mu \mathrm{m}$ were classified to genera. The average cell volume for each phytoplankton group identified in each sample was computed, by approximation to the nearest simple geometric shape, from the dimensions lat $1000 \times$ ) of ca 20 measured cells. Conversion to cellular carbon was performed according to Strathmann's (1967) non-linear equations for vacuolate diatoms and non-vacuolated algae. The biovolume $\left(\mu \mathrm{m}^{3} \mathrm{ml}^{-1}\right)$ of the different phytoplankton groups in each sample was calculated as the product of the cell density (cells $\mathrm{ml}^{-1}$ ) and average cell volume $\left(\mu \mathrm{m}^{3} \mathrm{cell}^{-1}\right)$. Error (as the coefficient of variation in cell densities among replicate bags was between 16 and $31 \%$, depending on the taxon.

Phytoplankton growth rates $\left(\mu, \mathrm{d}^{-1}\right)$ were calculated from changes in cell density $(D)$ with time $(t, d)$ for each group considered using the equation

$$
\mu=\frac{\ln \left(\frac{D_{t}}{D_{0}}\right)}{t}
$$

The error among replicate bags determined the detection limit of growth rate inside the dialysis bags to be between 0.07 and $0.11 \mathrm{~d}^{-1}$ and between 0.03 and
$0.05 \mathrm{~d}^{-1}$ depending on the taxon and whether the bags were incubated for 4 or $8 \mathrm{~d}$, respectively. The detection limits for community growth rate based on chl a and total biovolume were 0.02 and $0.07 \mathrm{~d}^{-1}$, respectively. Rates calculated from the changes in phytoplankton concentrations between the periods of bags collection in ambient waters and inside the dialysis bags (2 replicates each) were used to represent the net population change $\left(\mu_{n s i t u}\right)$ and the population change inside the dialysis bags $\left(\mu_{\text {bao }}\right)$, respectively (Tóth 1980, Furnas $1982,1990)$. Acccordingly, loss rates $\left(\mu_{\text {loss }}\right)$ were calculated as the difference between growth rates and the net rates of population change.

\section{RESULTS AND DISCUSSION}

Surface water temperature and salinity varied slightly during the period of the study (Table 1). The thickness of the mixed layer varied considerably within and among stations during the study, showing average values of $14.5 \pm 2.7 \mathrm{~m}$ (mean $\pm \mathrm{SE}$ ) in Sur Bay, $13.7 \pm 6.5 \mathrm{~m}$ in Falsa Bay, and $50.0 \pm 4.8 \mathrm{~m}$ in Foster Port. Fluorescence increased from the surface to reach a maximum at 12 to $20 \mathrm{~m}$, and showed considerable vertical structure at all stations, with the fluorescence profiles being more homogeneous in Foster Port. The persistence of vertical heterogeneity in phytoplankton abundance during the study indicated that the surface waters were not being mixed down to the depth of potential mixing inferred from density profiles. The photic layer $(>1 \%$ of surface irradiance) was $30 \mathrm{~m}$ deep, but underwater surface irradiance was generally low (typically $<112 \mu \mathrm{E}$ PAR $\mathrm{m}^{-2} \mathrm{~s}^{-1}$ ) due to dense cloud cover over the study period. Occasional short (1 to $2 \mathrm{~h}$ ) periods of clear sky led to high incident irradiances $\left(>2500 \mu \mathrm{E}\right.$ PAR $\mathrm{m}^{-2} \mathrm{~s}^{-1}$ ). The threshold between limiting and saturating irradiance for photosynthesis of subsurface $(5 \mathrm{~m})$ phytoplankton remained at about $50 \mu E$ PAR $\mathrm{m}^{-2} \mathrm{~s}^{-1}$ (M. P. Satta pers. comm.), similar to values reported elsewhere for Antarctic phytoplankton (Tilzer et al. 1986, Rivkin et al 1989). Hence, incident irradiance was generally sufficient to saturate photosynthesis of subsurface phytoplankton. The concentration of inorganic nutrients in the mixed layer remained high during the study period (phosphate $=1.29 \pm 0.05$ $\mu \mathrm{mol} l^{-1}$ (range 0.11 to 3.16), nitrate $=26.98 \pm 0.62 \mu \mathrm{mol}$ $1^{-1}$ (range 5.19 to 46.61$)$, and silicate $=47.15 \pm 0.99 \mu \mathrm{mol}$ $\mathrm{l}^{-1}$ (range 14.18 to 63.04)]. These conditions were maintained throughout the experiments, since no significant change in water mass properties (Table 1) was observed during the daily time series established and the ambient phytoplankton community remained stable, further indicating the absence of water mass replacement within the study sites. 
Table 1. Biomass, temperature (T), salinity (S), spectral irradiance, and thickness of the upper mixed layer (UPM) in February 1994 at Sur Bay, Falsa Bay, and Foster Port, Antarctica. -; not measured

\begin{tabular}{|c|c|c|c|c|c|c|c|}
\hline Location & $\begin{array}{l}\text { Expt } \\
\text { no. }\end{array}$ & $\begin{array}{l}\text { Date } \\
(1994)\end{array}$ & $\begin{array}{l}\text { Biomass } \\
\text { (chl a mg m i) }\end{array}$ & $\begin{array}{c}\mathrm{T} \\
\left({ }^{\circ} \mathrm{C}\right)\end{array}$ & $\underset{(1 /(1))}{S}$ & $\begin{array}{c}\text { Irradiance } \\
\left(\mu \mathrm{E} \text { PAR } \mathrm{m}^{-2} \mathrm{~s}^{-1}\right)\end{array}$ & $\begin{array}{c}\operatorname{UPM}(\mathrm{m}) \\
(\mathrm{n}=14 \\
\text { avg } \pm \text { est. })\end{array}$ \\
\hline \multirow[t]{8}{*}{ Sur Bay } & 1 & Feb 7 & 1.46 & 1.49 & 33.89 & 607.60 & \multirow[t]{8}{*}{$14.5 \pm 2.7$} \\
\hline & & Feb 11 & 0.90 & 1.38 & 33.80 & 348.55 & \\
\hline & & Feb 14 & 1.45 & 1.67 & 33.94 & 571.64 & \\
\hline & 2 & Feb 14 & 1.45 & 1.67 & 33.94 & 571.64 & \\
\hline & & Feb 17 & 1.51 & 1.69 & 33.83 & 751.08 & \\
\hline & & Feb 24 & 1.32 & 1.14 & 34.00 & - & \\
\hline & 3 & Feb 18 & 1.50 & 1.79 & 33.92 & 728.73 & \\
\hline & & Feb 24 & 1.32 & 1.14 & 34.00 & - & \\
\hline \multirow[t]{7}{*}{ Falsa Bay } & 1 & Feb 11 & 1.13 & 1.25 & 33.76 & 348.55 & \multirow[t]{7}{*}{$13.77 \pm 6.52$} \\
\hline & & Feb 13 & 1.44 & 1.52 & 33.89 & 187.22 & \\
\hline & & Feb 15 & 2.80 & 1.56 & 33.87 & 777.90 & \\
\hline & 2 & Feb 15 & 2.80 & 1.56 & 33.87 & 777.90 & \\
\hline & & Feb 19 & 1.12 & 1.43 & 33.78 & 742.80 & \\
\hline & 3 & Feu $1 \overrightarrow{7}$ & 0.92 & 1.61 & 3386 & 751.08 & \\
\hline & & Feb 21 & 0.38 & 1.24 & 33.99 & 916.47 & \\
\hline \multirow[t]{2}{*}{ Foster Port } & 1 & Feb 6 & 1.79 & 1.39 & 33.92 & 687.00 & \multirow[t]{2}{*}{$50 \pm 4.82$} \\
\hline & & Feb 21 & 1.04 & 1.36 & 33.93 & 916.47 & \\
\hline
\end{tabular}

Phytoplankton biomass in the surface waters sampled was relatively low $\left(0.9\right.$ to $2.8 \mathrm{mg} \mathrm{chl} \mathrm{a} \mathrm{m}^{-3}$, Table 1), despite the observation of a moderate phytoplankton bloom in 2 of the sites: 2.8 and $3.76 \mathrm{mg} \mathrm{chl}$ a $\mathrm{m}^{-3}$ in Falsa Bay and Foster Port, respectively (S. Agustí unpubl.). The phytoplankton communities growing in these coastal sites were dominated by large diatoms that represented $70 \%$ of phytoplankton biovolume. Biomass was dominated by Thalassiosira sp., which was present in 2 distinct size forms in the phytoplankton communities of Sur Bay and Falsa Bay (mean cell volumes of $3761 \mu^{3}$ and $70764 \mu^{3}$ ). The larger Thalassiosira sp. cells contributed 69 and $52.5 \%$ of the total phytoplankton biovolume of Sur and Falsa Bay, respectively, compared to 7 and $7.35 \%$ for the small Thalassiosira sp. cells, respectively. The phytoplankton community at Foster Port was mixed with similar contributions of Chaetoceros sp., Nitzschia sp. and small Thalassiosira sp. to biovolume.

Phytoplanklon biomass increased greatly inside the dialysis bags, reaching chl a concentrations of 5.9 and

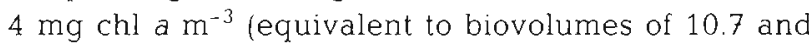
$6.4 \times 10^{6} \mathrm{\mu m}^{3} \mathrm{ml}^{-1}$, respectively) at Sur Bay and Falsa

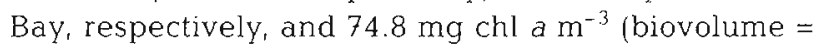

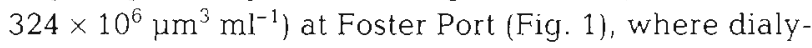
sis bags were incubated twice as long as in the other experiments (Table 1). The increase of chl a inside the dialysis bags, which represents the community growth rate, showed differences among experiments (Fig. 2). The increase in phytoplankton biomass inside the dialysis bags allowed calculation of community growth rates, which varied using either chl a or community biovolume as the basis of the calculations (correlation coefficient between chl $\mathrm{a}$ and community biovolume $=$ $0.83, p<0.0001)$. The calculated community growth rates reached moderately high values and showed considerable variation within and among stations (Table 2).

Microphytoplanktonic communities $(20 \mu \mathrm{m}<$ cell diameter $<200 \mu \mathrm{m}$ ) grew in response to confinement inside the dialysis cultures, while the picophytoplankton community (cell diameter $<5 \mu \mathrm{m}$ ) did not increase and frequently decreased. Potential grazers for diatoms in the area were represented by large species

Table 2. Growth rates, expressed as chlorophyll a and biovolume increments, of the sampled Antarctic phytoplankton community during the different dialysis experiments

\begin{tabular}{|c|c|c|c|c|}
\hline \multirow[t]{2}{*}{ Location } & \multirow{2}{*}{$\begin{array}{c}\text { Expt } \\
\text { no. }\end{array}$} & \multirow[t]{2}{*}{ Day } & \multicolumn{2}{|c|}{ Growth rate $\left(\mathrm{d}^{-1}\right)$} \\
\hline & & & Chl a & Biovolume \\
\hline \multirow[t]{5}{*}{ Sur Bay } & 1 & 4 & 0.11 & 0.65 \\
\hline & & 7 & 0.32 & 0.20 \\
\hline & 2 & 3 & 0.27 & 0.03 \\
\hline & & 7 & 0.03 & 0.28 \\
\hline & 3 & 6 & 0.14 & 0.48 \\
\hline \multirow[t]{4}{*}{ Falsa Bay } & 1 & 2 & 0.48 & 0.60 \\
\hline & & 4 & -0.01 & -0.06 \\
\hline & 2 & 4 & 0.09 & 0.57 \\
\hline & 3 & 4 & 0.20 & 0.35 \\
\hline Foster Port & 1 & 15 & 0.25 & 0.39 \\
\hline
\end{tabular}



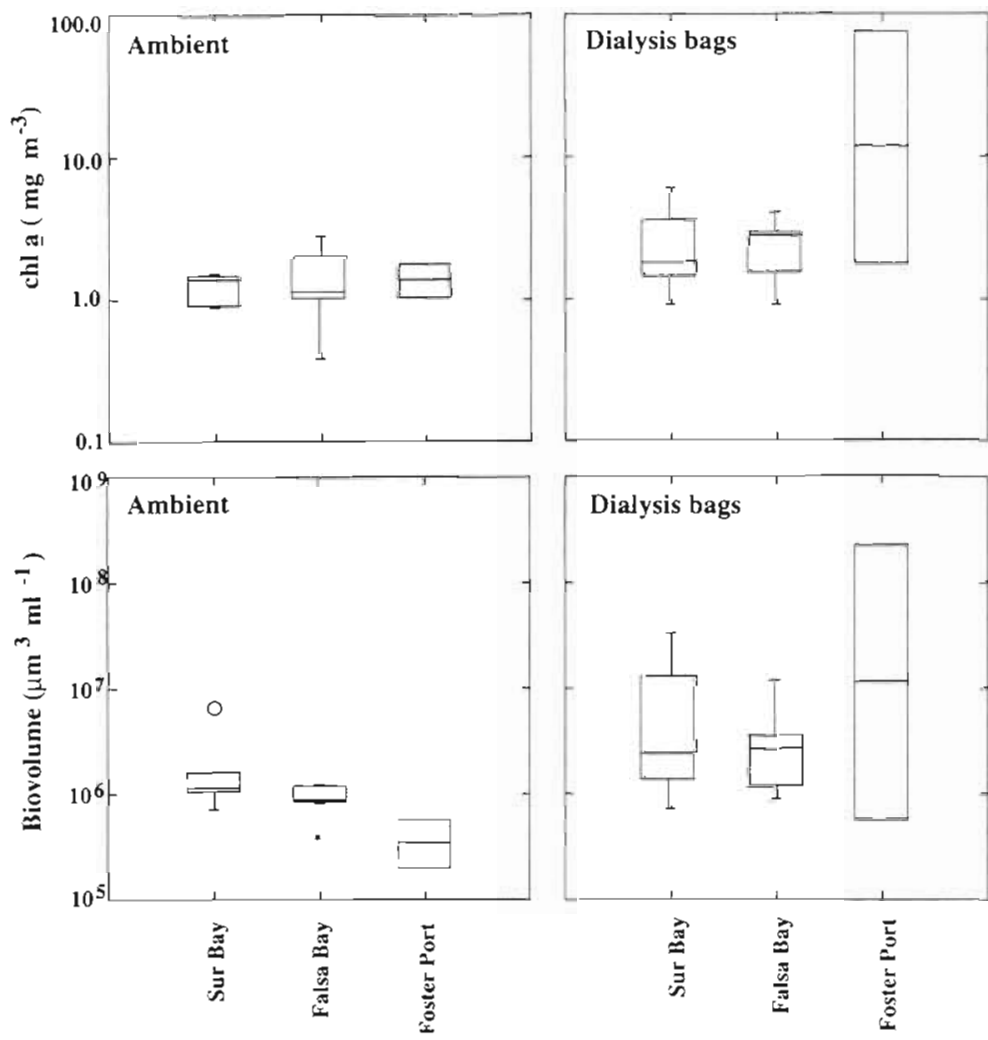

Fig. 1. Distribution of chlorophyll a concentration and phytoplankton biovolume, both in the natural community and in the dialysis bags, for the 3 Antarctic coastal sites studied. Plot made by pooling all of the values measured in the ambient waters, and all of the intermediate and final values measured inside the dialysis bags. Boxes and bars encompass 50 and $95 \%$ of the data, respectively, and the central line represents the median. Asterisk and empty circle in ambient brolvolume plot represents outlier and extreme value, respectively

(salps and krill, B. Vidondo unpubl.) that were effectively excluded from the dialysis bags. Small protists, which often graze picophytoplankton (Rassoulzadegan \& Sheldon 1986, Kuuppo-Leinikki 1990, Legendre \& Rassoulzadegan 1995), were, however, not removed by screening $(150 \mu \mathrm{m})$, and could account for the absence of picophytoplankton growth inside the bags (e.g. Mura et al. 1996). Microphytoplankton (diatoms) inside the dialysis bags grew in the absence of losses due to grazing, advection or sinking; thus, growth rates calculated for this organisms approximate to gross growth rates.

Chaetoceros sp. and Nitzschia sp. present in the phytoplankton community of Sur Bay grew in some of the experiments (e.g. Expts 1 and 3) from quite low densities in the natural communities to reach considerable densities inside the dialysis bags, after a lag of about 3 to 4 d (Fig 3). Both Thalassiosira sp. types (large and small) increased exponentially in all the experiments performed at Sur Bay (Fig. 3), with the larger Thalassiosira sp. cells being the only phyto- plankton group growing in the third experiment (Fig. 3). A similar pattern was observed at Falsa Bay, where the large Thalassiosira sp. cells dominated the community at the start of the experimental period, with Chaetoceros sp. and Nitzschia sp. populations developing substantial densities inside the bags (Fig. 3). The natural community comprised similar biomasses of Chaetoceros sp. and small Thalassiosira sp. at the time the third experiment was initiated in Falsa Bay, with the small Thalassiosira sp. cells showing the greatest increase in cell density. The phytoplankton community of Foster Port was comprised of smaller cells than those at the other 2 sites. The experiment retrieved in Foster Port showed a major increase in the abundance of small Thalassiosira sp., Chaetoceros sp. and Nitzschia sp. (Fig. 3).

Growth rates of diatom populations inside dialysis bags varied greatly both within and among taxa at Sur Bay, with the highest growth rates reaching $0.35 \mathrm{~d}^{-1}$ to $0.78 \mathrm{~d}^{-1}$, depending on the taxon (Table 3). However, growth was not always detected inside the dialysis bags. For example, growth in Expt 3 at Sur Bay was only observed for large Thalassiosira sp. (Fig. 3), and both large and small Thalassiosira sp., but not Chaetoceros sp. or Nitzschia sp., grew in Expt 2 in Falsa Bay (Fig. 3). The in situ rate of population change observed in the ambient community was negative for Chaetoceros sp., and showed both negative and positive values for the other taxa (Table 3). Positive in situ rates of population change were observed dur. ing a small bloom of the ambient community, with the in situ rate of population change reaching 0.47 and $0.34 \mathrm{~d}^{-1}$ for Nitzschia sp. and small Thalassiosira sp., respectively (Table 3 ). Chaetoceros sp. experienced the highest population loss rates at Sur Bay (up to 1.05 $\mathrm{d}^{-1}$ ), which resulted in a decline in the ambient Chaetoceros sp. population in Sur Bay for the duration of the study. Important loss rates were also observed for the other phytoplankton groups at Sur Bay, reaching about 0.63 and $0.57 \mathrm{~d}^{-1}$ for Nitzschia sp. and small Thalassiosira sp., respectively (Table 3 ). The population growth rates observed at Falsa Bay were highest for Chaetoceros sp., Nitzschia sp. and large Thalassiosira sp. The ambient Chaetoceros $\mathrm{sp}$. population showed strongly negative $\left(-0.56 \mathrm{~d}^{-1}\right)$ in situ rates of population change, indicative of high population loss rate (up to $0.88 \mathrm{~d}^{-1}$, Table 3 ). In fact, population loss 

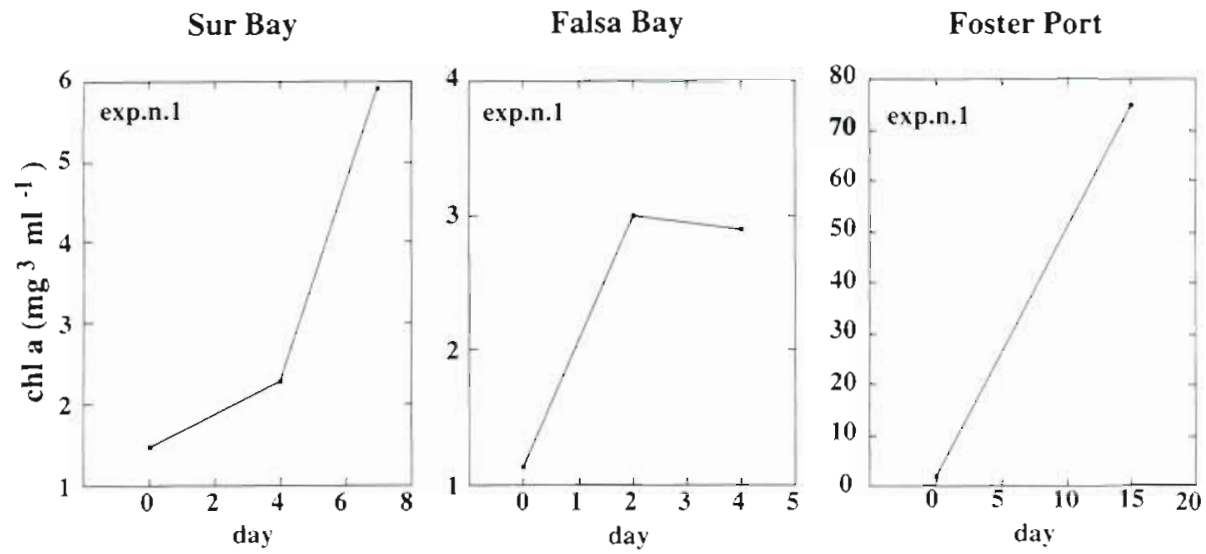

Fig. 2. Temporal evolution of the chorophyll a concentration inside dialysis bags following the variation of community biomass during the experiments at the 3 Antarctic coastal sites studied
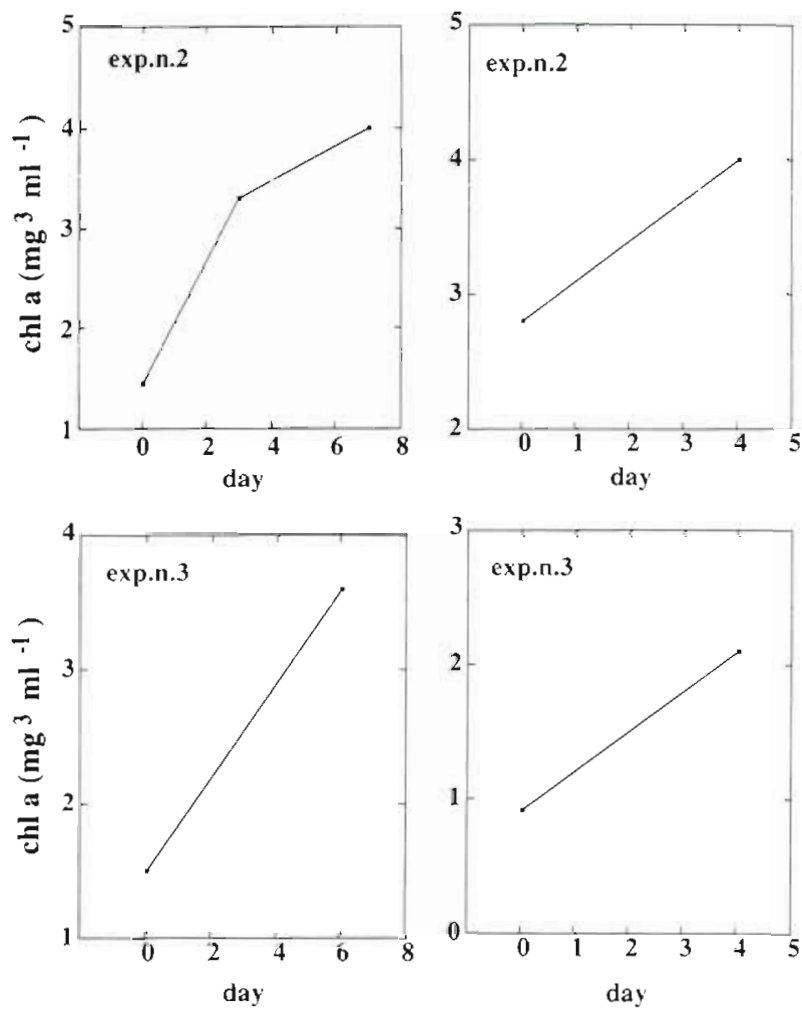

the bags suggests that the coastal Antarctic microphytoplankton assemblages experience substantial loss rates $\left(45 \pm 0.4 \mathrm{~d}^{-1}\right.$ ) (Table 3 ). These results support previous contentions that losses are important controlling factors for Antarctic phytoplankton (Frost 1987, 1991, Banse 1990). Although losses by sinking and advection were not quantified, grazing by krill and salps in these bays, examined in concurrent experiments abodrd ( $B$ Vidondo unpubl.) were considerable, and probably made an important contribution to phytoplankton losses.

The highest growth rates observed for the diatom species dominating the microplankton community often exceeded published values for Antarctic phytoplankton (Holm-Hansen et al. 1977, El-Sayed \& Taguchi 1981. Figueiras et al 1994). Antarctic diatoms are well adapted to the environmental conditions and achieve relatively fast growth at this low temperature (Priddle et al. 1986, Spies 1987). We evaluated whether the highest population growth rates observed here approach the maximal growth rates possible by comparing the highest rates observed in our study with the maximal growth rates predicted at the in situ temperature from the cell size of the taxa. Banse (1982) described the size-dependence of maximal marine diatom growth rates $\left(\mu_{\max }, \mathrm{d}^{-1}\right)$ at $20^{\circ} \mathrm{C}$ under favourable conditions using the equation $\mu_{\max }=3.02 \mathrm{~W}^{-0.13}$, where $W$ is cell carbon in pg. The validity of this relationship has been recently confirmed by Thang (1995). Maximal growth rates at other growth temperatures have been obtained by applying a $Q_{10}$ for growth of 1.88 (Eppley 1972) to the original equation of Banse (Sommer 1989). Using this procedure, we arrived at the equation, $\mu_{\max }=0.845 \mathrm{~W}^{-0.13}$ to predict maximal diatom growth at $1.5^{\circ} \mathrm{C}$, the mean temperature of the Antarctic waters sampled in this study. This equation predicts maximal diatom growth rates at $1.5^{\circ} \mathrm{C}$ to be $30 \%$ of those at $20^{\circ} \mathrm{C}$, both experiencing a similar decline with size. Laboratory experiments, however, have provided 
Sur Bay
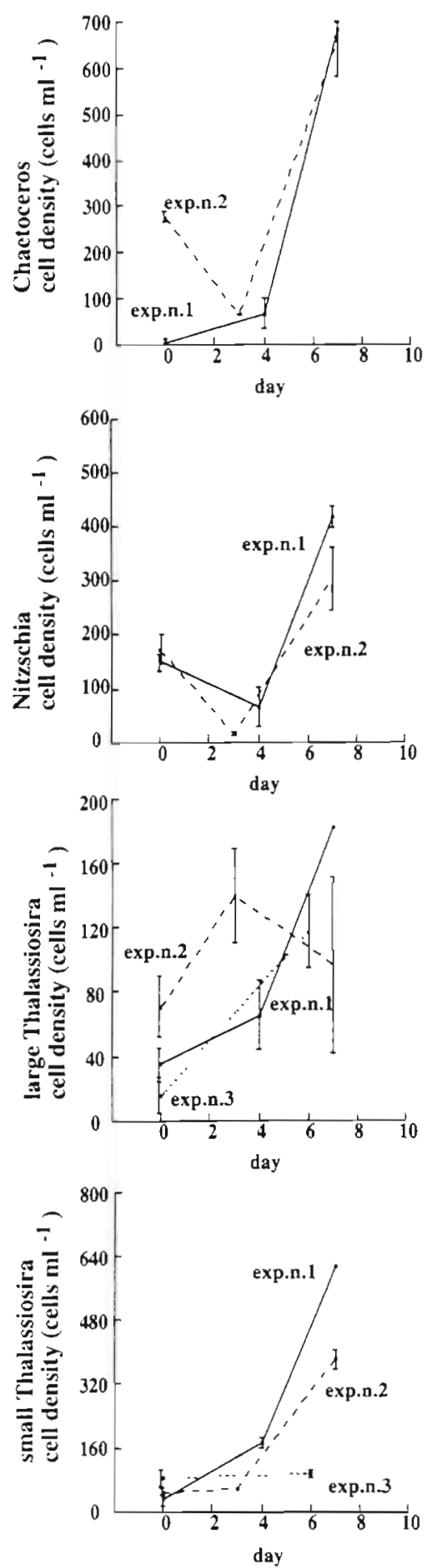

Falsa Bay

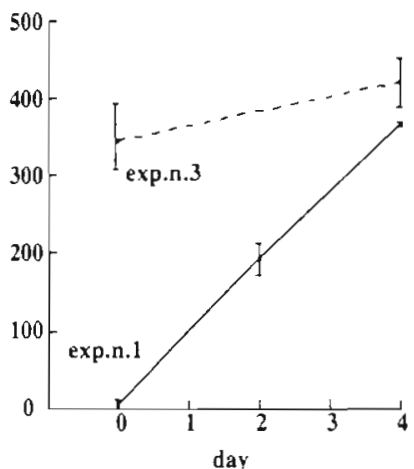

day
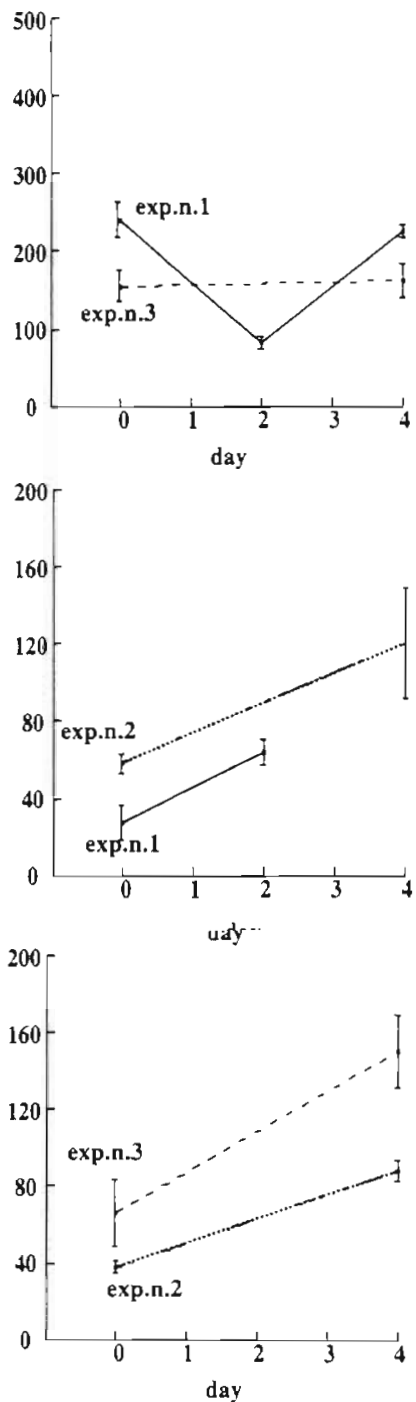

\section{Foster Port}
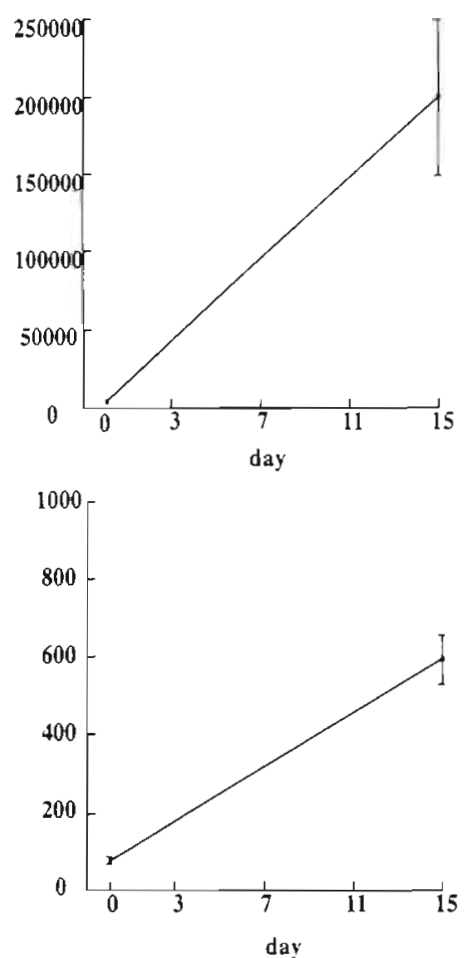

day

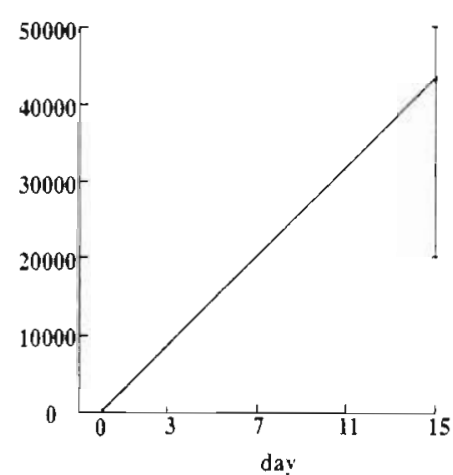

Fig. 3. Chaetoceros sp., Nitzschia sp. and Thalassiosira sp. Temporal evolution of the cell density ( \pm SE) of the dominant microphytoplankton groups present in the dialysis bags at the 3 Antarctic coastal sites studied. SE was calculated between replicate bags for the samples collected at time intervals $\geq 2 \mathrm{~d}$. The SE at the initial time represents the counting error. Different line styles indicate 
Table 3. Chaetoceros sp., Nitzschia sp. and Thalassiosira sp. Growth rates $\left(\mu_{\text {bay }}\right)$, net rates of population change $\left(\mu_{t r}\right.$ stu $)$, and population loss rates $\left(\mu_{\text {ioss }}\right)$ of Antarctic microphytoplanktonic diatoms during dialysis expenments at 3 different stations under natural environmental conditions. - $\mu_{\text {loss }}$ could not be caIculated whenever $\mu_{\text {bag }}$ was below the detection limit for growth. (No large Thalassiosira sp. were present at Foster Port)

\begin{tabular}{|c|c|c|c|c|}
\hline & $\begin{array}{c}\text { Expt } \\
\text { no. }\end{array}$ & $\begin{array}{l}\mu_{\mathrm{bag}} \\
\left(\mathrm{d}^{-1}\right)\end{array}$ & $\begin{array}{l}\mu_{i n s i n} \\
\left(\mathrm{~d}^{-1}\right)\end{array}$ & $\begin{array}{l}\mu_{\text {lows }} \\
\left(d^{-1}\right)\end{array}$ \\
\hline \multicolumn{5}{|l|}{ Sur Bay } \\
\hline \multirow[t]{5}{*}{ Chaetoceros sp. } & 1 & 0.76 & -0.29 & 1.05 \\
\hline & 1 & 0.78 & -0.21 & 0.99 \\
\hline & 2 & $<0.10$ & 0.45 & - \\
\hline & 2 & 0.28 & -0.21 & 0.49 \\
\hline & 3 & $<0.10$ & -0.13 & - \\
\hline \multirow[t]{5}{*}{ Nitzschia sp. } & 1 & $<0.07$ & -0.32 & - \\
\hline & 1 & 0.62 & 0.47 & 0.15 \\
\hline & 2 & $<0.07$ & 0.51 & - \\
\hline & 2 & 0.42 & -0.21 & 0.63 \\
\hline & 3 & $<0.07$ & 0.03 & - \\
\hline \multirow[t]{5}{*}{ Large Thal. sp. } & 1 & 0.16 & 0.17 & -0.01 \\
\hline & 1 & 0.34 & 0.02 & 0.32 \\
\hline & 2 & 0.23 & -0.02 & 0.25 \\
\hline & 2 & $<0.05$ & -0.03 & - \\
\hline & 3 & 0.35 & 0.21 & 014 \\
\hline \multirow[t]{5}{*}{ Small Thal.sp. } & 1 & 0.45 & -0.12 & 0.57 \\
\hline & 1 & 0.42 & 0.34 & 0.08 \\
\hline & 2 & $<0.07$ & -0.08 & - \\
\hline & 2 & 0.27 & 0.10 & 0.17 \\
\hline & 3 & $<0.07$ & -0.01 & - \\
\hline \multicolumn{5}{|l|}{ Falsa Bay } \\
\hline \multirow[t]{4}{*}{ Chaetoceros sp. } & 1 & 0.69 & -0.24 & 0.93 \\
\hline & 1 & 0.32 & -0.56 & 0.88 \\
\hline & 2 & $<0.10$ & -0.24 & - \\
\hline & 3 & $<0.10$ & -0.38 & - \\
\hline \multirow[t]{4}{*}{ Nitzschia sp. } & 1 & $<0.07$ & 0.07 & - \\
\hline & 1 & 0.5 & -0.09 & 0.59 \\
\hline & 2 & $<0.07$ & 0.01 & - \\
\hline & 3 & $<0.07$ & -0.09 & - \\
\hline \multirow[t]{4}{*}{ Large Thal sp. } & 1 & 0.41 & 0.11 & 0.30 \\
\hline & 1 & $<0.11$ & -0.40 & - \\
\hline & 2 & 0.36 & 0.21 & 0.15 \\
\hline & 3 & $<0.11$ & 0.16 & - \\
\hline \multirow[t]{4}{*}{ Small Thal.sp. } & 1 & $<0.07$ & -0.19 & - \\
\hline & 1 & $<0.07$ & -0.31 & - \\
\hline & 2 & 0.21 & 0.13 & 0.08 \\
\hline & 3 & 0.20 & -0.07 & 0.27 \\
\hline \multicolumn{5}{|l|}{ Foster Port } \\
\hline Chaetoceros sp. & 1 & 0.26 & -0.06 & 0.32 \\
\hline Nitzschia sp. & 1 & 0.11 & -0.03 & 0.14 \\
\hline Small Thal. sp. & 1 & 0.46 & 0.03 & 0.49 \\
\hline
\end{tabular}

evidence of a weaker size-dependence of maximal growth rates for Antarctic phytoplankton (allometric exponent $=-0.08$, Sommer 1989 ) than predicted by the modified equation of Banse (1982). Our results, however, show a significant decline $(r=0.84, p<0.025)$ in the highest growth rate reached by the coastal Antarctic phytoplankton populations studied with increasing

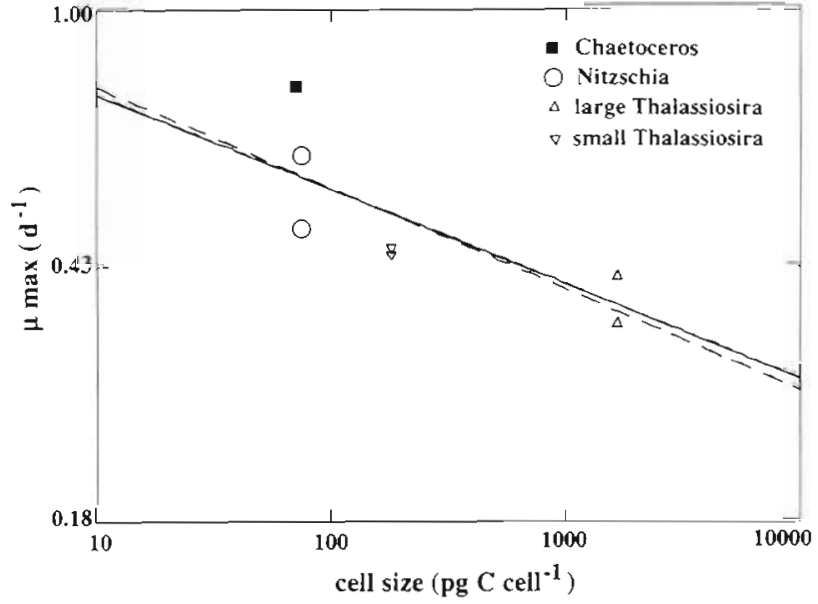

Fig. 4. The relationship between the maximal growth rate $\left(\mu_{\text {mox }}, \mathrm{d}^{-1}\right)$ observed for the main phytoplankton groups at the 3 Antarctic coastal sites studied and average cell size. Solid line represents the relationship of Banse (1.982) recalculated for diatoms grown at $1.5^{\circ} \mathrm{C}$, and dasned line represents the fitted regression equation

cell size (Fig 4). The size-dependent decline in the highest growth rates measured for the different populations examined is remarkably close to that predicted for the maximal growth rate by the equation of Banse (1982) adapted to the in situ temperature of $1.5^{\circ} \mathrm{C}$ (Fig. 4).

Our results, therefore, suggest that natural Antarctic diatoms assemblages often display growth rates as high as the maximal growth rates predicted from cell sizes at the low in situ temperature. Temperature, therefore, imposes an upper limit to the highest growth rates of natural Antarctic phytoplankton, which is 3 -fold lower than that at $20^{\circ} \mathrm{C}$. Because of the constancy of temperature in Antarctic waters, it cannot explain variations in the growth rate of phytoplankton communities. Our results provide evidence that the relatively high growth rates achievable by natural Antarctic phytoplankton communities can be counterbalanced by similarly high loss rates, resulting in a relatively uniform biomass. The low biomass, relative to resources, that Antarctic phytoplankton communities display is not, therefore, a consequence of sustained slow growth rates, but rather of a tendency towards an overall balance between growth and loss rates.

Acknowledgements. This work was supported by a grant, ANT93-0490, from CICYT (Spanish Commission of Science and Technology. M.P.M. was supported by a grant from the CEE. We thank Mario Manriquez for CTD data and the 'BlOHespérides' crew for their professional assistance and friendship dunng the cruise. We thank also Mana Paola Satta, Beatriz Vidondo and Neus Martinez for their collaboratıon during sampling and elaboration of the data. We are specially grateful to C. M. Duarte and R. B. Rivkin for useful comments on the manuscript. 


\section{LITERATURE CITED}

Banse K (1982) Cell volumes, maximal growth rates of unicellular algae and ciliates, and the role of ciliates in the marine pelagial. Limnol Oceanogr 27:1059-1071

Banse K (1990) Does iron really limit phytoplankton production in the offshore subarctic Pacific? Limnol Oceanogr 35: $772-775$

El-Sayed SZ, Taguchi S (1981) Primary production and standing crop of phytoplankton along the ice-edge in the Weddell Sea. Deep Sea Res 28A:1017-1032

Eppley RW (1972) Temperature and phytoplankton growth in the sea. Fish Bull 70:1063-1085

Figueiras FG, Pérez FF, Pazos Y, Rios AF (1994) Light and productivity of Antarctic phytoplankton during austral summer in an jce edge region in the Weddell-Scotia Sea. J Plankton Res 16(3):233-253

Frost BW (1987) Grazing control of phytoplankton stock in the open subarctic Pacific Ocean: a model assessing the role of meso-zooplankton, particularly the large calanoid copepods Neocalanuss spp. Mar Ecol Prog Ser 39:49-68

Frost BW (1991) The role of grazing in nutrient rich areas of the open sea. Limnol Oceanogr 36(8):1616-1630

Furnas MJ (1982) Growth rate of summer nanoplankton $(<10 \mu \mathrm{m})$ populations in lower Narragansett Bay, Rhode Island, USA. Mar Biol 70:105-115

Furnas MJ (1990) In situ growth rates of marine phytoplankton: approaches to measurement, community and species growth rates. J Plankton Res 12(6):1117-1151

Goldman JC, Carpenter EJ (1974) A kinetic approach to the effect of temperature in algal growth. Limnol Oceanogr $19(5): 756-766$

Hasle G (1969) An analysis of the phytoplankton of the Pacific Southern Ocean: abundance, composition and distribution during the Brategg Expedition, 1947-48. Hvalrádets Skrifter 52:1-168

Holm-Hansen O, El-Sayed SZ, Franceschini GA, Cuhel RL (1977) Primary production and the factor controlling phytoplankton growth in the Southern Ocean. In: Llano GA (ed) Adaptations within Antarctic ecosystems. Gulf Publishing, Houston, p 11-50

Holm-Hansen O, Riemann B (1978) Chlorophyll a determination improvements in methodology. Oikos 30:438-447

Kuuppo-Leinikki P (1990) Protozoan grazing on planktonic bacteria and its impact of on bacteria population. Mar Ecol Prog Ser 63:227-238

Jaques G (1983) Some ecophysiological aspects of Antarctic phytoplankton. Polar Biol 2:27-33

Legendre L, Rassoulzadegan F (1995) Plankton and nutrient dynamics in marine waters. Ophelia 41:153-172

Mann KA, Lazıer SRN (1991) Dynamics of marine ecosystems Blackwell Scientific Publication, Cambridge

Martinussen l, Thingstad TF (1991) A simple double stamning technique for simultaneous quantification of auto- and heterotrophic nano- and picoplankton. Mar Microb Food Webs 5(1):5-11

This artucle was submitted to the editor
Mitchell BG, Holm-Hansen O (1991) Observation and modelling of the Antarctic phytoplankton crop in relation of mixing depth. Deep Sea Res 38:981-1007

Mura MP, Agustí S, del Giorgio PA, Gasol JG, Vaqué D, Duarte CM (1996) Loss-controlled pytoplankton production in nutrient-poor littoral water of the NW Mediterranean: in situ experimental evidence. Mar Ecol Prog Ser 130:213-219

Mura MP, Agustí S, Satta MP (1995) Water-mass influences on summer Antarctic phytoplankton biomass and community structure. Polar Biol 15:15-20

Neory A, Holm-Hansen $O$ (1982) Effect of temperature on rates of photosynthesis in Antarctic phytoplankton. Polar Biol 1:33-38

Parsons TR, Maita Y, Lalli CM (1984) A manual of chemical and biological methods for seawater analysis. Pergamon Press, Oxford

Priddle J, Hawes I, Ellıs-Evans JC (1986) Antarctic aquatic ecosystems as habitats for phytoplankton. Biol Rev 61. $199-238$

Rassoulzadegan F, Sheldon RW (1986) Predator-prey interactions of nanozooplankton and bacteria in an oligotrophic marine environment. Limnol Oceanogr 31(5): 1010-1021

Rivkin RB, Putt M, Alexander SP, Meritt D, Gaudet L (1989) Biomass and production in polar planktonic and sea ice microbial communities: a comparative study. Mar Biol 101: $273-283$

Sakshaug E, Holm-Hansen O (1984) Factors governing pelagic production in polar ocean. In: Holm-Hansen $\mathrm{O}$, Bolis L, Gilles R (eds) Marine phytoplankton and productivity. Lecture notes on coastal and estuarine studies, Vol 8. Springer, Berlin, p 1-17

Sommer U (1989) Maximal growth rates of Antarctic phytoplankton: only a weak dependence on cell size. Limnol Oceanogr 34(6): 1109-1112

Spies A (1987) Growth rates of Antarctic marine phytoplankton in the Weddell Sea. Mar Ecol Prog Ser 41:267-274

Strathmann RR (1967) Estimating the organic carbon content of phytoplankton from cell volume or plasma volume. Limnol Oceanogr 12:411-418

Thang EPY (1995) The allometry of algal growth rates. J Plankton Res 17(6):1325-1335

Tilzer MM, Dubinsky Z (1987) Effects of temperature and day length on the mass balance of Antarctic phytoplankton. Polar Biol 7:35-42

Tilzer MM, Elbrächter M, Gieskes WW, Beese B (1986) Lighttemperature interaction in the control of photosynthesis in Antarctic phytoplankton. Polar Biol 5:105-111

Tóth LG (1980) The use of dialysing sacks in estimation of production of bacterioplankton and phytoplankton. Area Hydrobıol 89:474-482

Whitledge TE, Malloy SC, Patton CJ and Wirick CD (1981) Automated nutrient analyses in seawater. Brookhaven National Laboratory, US Dept of Energy and Environment, Upton, NY

Manuscript first received: February 22, 1996

Revised version accepted: October 14, 1996 